\title{
Arterial stiffness may predict renal and cardiovascular prognosis in autosomal-dominant polycystic kidney disease
}

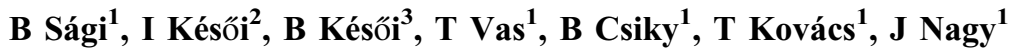 \\ ${ }^{1}$ 2nd Department of Internal Medicine and Nephrological Centre, Clinical Centre, Medical School, \\ University of Pécs, Pécs, Hungary \\ ${ }^{2}$ Internal Medicine Department, Mining Rehabilitation and Night Time Sanatorium, Health Centre of \\ Komló, Komló, Hungary \\ ${ }^{3}$ Department of Adult Cardiology, György Gottsegen National Institute of Cardiology, Budapest, Hungary
}

Received: April 3, 2018

Accepted: June 2, 2018

\begin{abstract}
Background and aims: Autosomal-dominant polycystic kidney disease (ADPKD) is one of the most common causes of end-stage renal disease (ESRD). The most important cause of death among ADPKD patients is cardiovascular (CV). The aim of this study was to examine the prognostic significance of arterial stiffness on CV and renal outcomes in ADPKD. Methods: A total of 55 patients with ADPKD were examined. Pulse wave velocity was determined and stiffness index ( $\left.\mathrm{SI}_{\mathrm{DVP}}\right)$ was calculated. Combined primary endpoints (CV and renal) were major $\mathrm{CV}$ events (myocardial infarction, stroke, and CV intervention) as CV endpoints, and attaining of ESRD or start of renal replacement therapy as renal endpoints. Secondary endpoints were CV or renal endpoints separately. Results: The mean age of those $55 \mathrm{ADPKD}$ patients was $45 \pm 12$ years, 21 patients were male. The average value of the $\mathrm{SI}_{\mathrm{DVP}}$ was $11.11 \pm 2.22 \mathrm{~m} / \mathrm{s}$. The patients were divided into two groups by the cutoff value of $11 \mathrm{~m} / \mathrm{s}$ of $\mathrm{SI}_{\mathrm{DVP}}$ and then outcomes were analyzed. In the higher arterial stiffness group $\left(\mathrm{SI}_{\mathrm{DVP}}>11 \mathrm{~m} / \mathrm{s}\right)$, occurrence of combined primary endpoint (CV and renal) was significantly higher than in the group with more elastic arteries $(p=0.033)$. A statistically significant difference was found in the renal endpoints $(p=0.018)$, but not in the CV endpoints ( $p=0.952)$ between the two groups. Conclusions: Increased arterial stiffness predicts the onset of ESRD in ADPDK. Assessment of $\mathrm{SI}_{\mathrm{DVP}}$ appears to be a useful method for estimating the renal and CV prognosis in ADPKD.

Keywords: arterial stiffness, chronic kidney disease, autosomal-dominant polycystic kidney disease, renal function, renal prognosis
\end{abstract}

\section{Introduction}

Autosomal-dominant polycystic kidney disease (ADPKD) is the most common hereditary chronic kidney disease (CKD) with the prevalence of 1/400-1,000 live births (45). The majority of cases show autosomal-xdominant inheritance. Mutations of two genes, polycystin 1 (PC1) and polycystin 2 (PC2), are responsible for development of the disease; however, the precise pathogenic mechanism remains unknown (20). The mutant PC1 and PC2 proteins modify the function of renal tubular cells. As a result, epithelial cell proliferation segmentally develops in the renal tubuli, and the tubulointerstitial matrix may be disorganized leading to the formation of growing cysts of various sizes. The clinical picture of ADPKD is

Corresponding author: Prof. Judit Nagy MD, PhD, DSc

2nd Department of Internal Medicine and Nephrological Centre, Clinical Centre, Medical School, University of Pécs, Pacsirta street 1, 7624 Pécs, Hungary

Phone: +36 72530000 36074; Fax: +36 72536000 36072; E-mail: judit.nagy@aok.pte.hu 
characterized by the slow enlargement of the renal cysts, which gradually compress the normal kidney parenchyma, and thus the disease slowly progresses into end-stage renal disease (ESRD). The formation and enlargement of kidney cysts usually coexist with extrarenal CV manifestations, including intra- and extracranial aneurysms, heart valvular defects, and increased carotid intima-media thickness $(11,12,23)$.

It is widely accepted that vascular dysfunction is common in ADPKD and CV complications are mostly responsible for the increased mortality of ADPKD patients $(14,41)$. More than $80 \%$ of CV complications are associated with dysfunction and disorders of the arteries (15) and one of the greatest contributors to $\mathrm{CV}$ dysfunction is stiffening of the large elastic arteries (25).

The aim of this study was to determine vascular function and to evaluate the prognostic significance of arterial stiffness on renal function and CV events in ADPKD patients. We examined whether increased arterial stiffness could be an independent predictor of major $\mathrm{CV}$ events (myocardial infarction, stroke, revascularization, and cardiac death) or ESRD. We also purposed to determine the prognostic cutoff arterial stiffness value by photoplethysmography. Such data are lacking in the literature as arterial stiffness has not yet been assessed with photoplethysmography in renal patients.

\section{Methods}

\section{Participants}

This study was started between April 2007 and December 2008 at the 2nd Department of Internal Medicine and Nephrological Centre, University of Pécs with 60 patients who had ADPKD. Local ethics committee approved the clinical study protocol (no. 3170/2008) and written informed consents were obtained from all participants. The diagnosis of ADPKD was made on the basis of clinical picture, physical examination, and the typical abdominal ultrasound morphology. Exclusion criteria were severe clinical conditions (NYHA III-IV heart failure, stroke and myocardial infarction within 3 months, uncontrolled cardiac arrhythmia, malignant disease requiring active treatment, and ongoing infection with fever). Patients with ESRD (CKD stage 5), renal replacement therapy, or kidney transplant were also excluded from the study.

\section{Clinical assessment}

The modification of diet in renal disease formula was used to determine renal function [estimated glomerular filtration rate (eGFR): $\mathrm{ml} / \mathrm{min} / 1.73 \mathrm{~m}^{2}$ ]. The classical CV risk factors, such as hypertension, carbohydrate metabolism disorders (diabetes mellitus, impaired glucose tolerance, and elevated fasting glucose level), obesity, lipid abnormalities, and smoking, were also assessed at the first visit. The World Health Organization criteria were used for the definition of the metabolic syndrome. All enrolled patients were regularly examined at 3- to 6-month intervals (or more often if necessary). At visits, any adverse events since the last visit were interviewed, physical status was determined, and detailed laboratory tests were performed. Blood pressure was calculated as the average of three measurements after 10 min resting. Complete $\mathrm{CV}$ examinations (echocardiogaphy, ergometry, coronarography, etc.) were carried out when it seemed to be necessary based on the patients' complaints. Abdominal ultrasound was performed on all patients every 2 years.

On follow-up, five patients did not attend the check-ups, thus their data were not analyzed. 
Determination of vascular stiffness

We used the finger photoplethysmography method by the Pulse Trace System (Micro Medical Ltd., Rochester, UK) to assess pulse wave velocity (PWV) as described earlier $(21,22)$. This method allows the determination of the stiffness index (SI), which can be derived from the digital volume pulse (DVP), and is reflected as $\mathrm{SI}_{\mathrm{DVP}}$. Briefly, DVP includes two distinct waves during the cardiac cycle: an early systolic one that originates from the pressure wave at the time of the left ventricular ejection, which could be measured in the finger artery, followed by a second peak due to a reflected wave from more peripheral segments, which usually form the aortic bifurcation. The SI is derived from body height relative to the time difference between the forward and reflected pulse waves: $\mathrm{SI}_{\mathrm{DVP}}(\mathrm{m} / \mathrm{s})=$ height $/ \Delta t$. The recorded pulse curve profile is principally determined by the PWV of the large arteries $(8,18)$. Based on literature data, the results of the method used here correlate with those of other methods, such as the central aortic PWV (34). Higher $\mathrm{SI}_{\mathrm{DVP}}$ values indicate increased vascular stiffness $(2,6,33)$.

Patients were allowed to take their regular medications. The participants were asked not to smoke and not to drink coffee on the day of the examination. All subjects were examined in supine position after at least $10 \mathrm{~min}$ of resting. Single waveform was obtained by averaging the DVP profiles for $30 \mathrm{~s}$. To enhance the accuracy of the $\mathrm{SI}_{\mathrm{DVP}}$ measurements, five period samples were taken and the upper and lower values of DVP were deleted. The remaining three values were averaged and used for further analysis, including the variability test. All measurements were performed in the morning hours between 9 and 11 a.m., thereby eliminating confounding effects of the circadian variability.

The data analyser was unaware of clinical information of the patients.

\section{Statistical analysis}

All results are expressed as mean $\pm \mathrm{SD}$ for variables with normal distribution unless otherwise specified. Survival was examined by Mantel-Cox log-rank test. Cox regression analysis was used to evaluate the effects of factors on survival. Receiver operating characteristic (ROC) analysis was performed to determine the SI value that separates the two groups most appropriately for the outcome. Multivariate analysis was used to explore the factors that influence CV events and impaired renal function.

On the basis of the average SI value, the patients were divided into two groups at the cutoff point of $11 \mathrm{~m} / \mathrm{s}$, and the outcome of the two groups was analyzed and compared. The combined primary endpoint was the combination of myocardial infarction, stroke, or CV intervention as the CV endpoints or ESRD (CKD stage 5) and start of renal replacement therapy as the renal endpoints. Subsequently, CV and renal endpoints were analyzed separately as secondary endpoints.

Statistical analysis was performed using the SPSS software version 22.0, and $p$ value of $<0.05$ was considered as statistically significant.

\section{Results}

A total of 55 ADPKD patients (21 males, mean age: $45 \pm 12$ years) were analyzed. Patients were followed up for an average of $63 \pm 32$ months. The clinical characteristics and occurrence of CV risk factors are summarized in Table I. The mean $\mathrm{SI}_{\mathrm{DVP}}$ value was $11.11 \pm 2.22 \mathrm{~m} / \mathrm{s}$ and the patients were divided into two groups at this cutoff value. Table I 
Table I. Baseline characteristics of ADPKD patients

\begin{tabular}{|c|c|c|c|c|}
\hline & $\begin{array}{l}\text { ADPKD patients } \\
\quad(n=55)\end{array}$ & $\begin{array}{c}\mathrm{SI} \leq 11 \mathrm{~m} / \mathrm{s} \\
(n=27)\end{array}$ & $\begin{array}{c}\mathrm{SI}>11 \mathrm{~m} / \mathrm{s} \\
\quad(n=28)\end{array}$ & $p$ value \\
\hline Male/female $(n)$ & $21 / 34$ & $8 / 19$ & $13 / 15$ & 0.103 \\
\hline Age (year) & $45 \pm 12$ & $41 \pm 10^{*}$ & $49 \pm 11^{*}$ & 0.002 \\
\hline Follow-up time (month) & $63 \pm 32$ & $67 \pm 31$ & $58 \pm 33$ & 0.156 \\
\hline Duration of ADPKD (year) & $13.2 \pm 9.2$ & $12.8 \pm 8.5$ & $13.7 \pm 9.7$ & 0.364 \\
\hline eGFR (ml/min $\left./ 1.73 \mathrm{~m}^{2}\right)$ & $72 \pm 36$ & $82 \pm 37 * *$ & $61 \pm 31^{* *}$ & 0.013 \\
\hline Stiffness index $(\mathrm{m} / \mathrm{s})$ & $11.11 \pm 2.22$ & $9.44 \pm 1.41 * * *$ & $12.71 \pm 1.56^{* * *}$ & 0.001 \\
\hline \multicolumn{5}{|c|}{ Metabolic syndrome components } \\
\hline Obesity $[n(\%)]$ & $22(40)$ & $11(37)$ & $11(39)$ & 0.457 \\
\hline BMI $\left(\mathrm{kg} / \mathrm{m}^{2}\right)$ & 28.5 & 28.4 & 28.5 & 0.453 \\
\hline $\begin{array}{l}\text { Carbohydrate metabolic } \\
\text { disorders }[n(\%)]\end{array}$ & $13(24)$ & $5(18)$ & $8(28)$ & 0.194 \\
\hline Dyslipidemia $[n(\%)]$ & $26(47)$ & $13(48)$ & $13(46)$ & 0.450 \\
\hline Hypertension $[n(\%)]$ & $46(84)$ & $21(78)$ & $25(89)$ & 0.128 \\
\hline Metabolic syndrome $[n(\%)]$ & $13(24)$ & $5(18)$ & $8(28)$ & 0.194 \\
\hline Smoking $[n(\%)]$ & $20(36)$ & $9(33)$ & $11(39)$ & 0.326 \\
\hline ACEI/ARB therapy $[n(\%)]$ & $46(84)$ & $21(78)$ & $25(89)$ & 0.128 \\
\hline
\end{tabular}

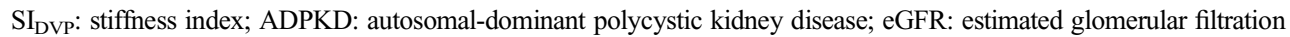
rate; BMI: body mass index; ACEI: angiotensin-converting enzyme inhibitor; ARB: angiotensin-receptor blocking agent. $* p=0.002$.

$* * p=0.013$

$* * * p=0.001$

shows the characteristic features of all patients and in the two subgroups. Patients with increased $\mathrm{SI}_{\mathrm{DVP}}\left(\mathrm{SI}_{\mathrm{DVP}}>11 \mathrm{~m} / \mathrm{s}\right)$ were significantly older $(p=0.002)$ and their renal function was significantly worse $(p=0.013)$.

The occurrence of primary combined and secondary endpoints in the two subgroups are shown in Table II and Fig. 1A and B. Figure 1A shows that probability of the combined primary endpoint (CV and renal) was significantly higher in the subgroup with increased stiffness $\left(\mathrm{SI}_{\mathrm{DVP}}>11 \mathrm{~m} / \mathrm{s}\right)$ compared to the group with more elastic arteries $\left(\mathrm{SI}_{\mathrm{DVP}} \leq 11 \mathrm{~m} / \mathrm{s}\right)$, $\left(\chi^{2}: 4.571 ; p=0.033\right)$. For the $\mathrm{CV}$ endpoint, there was no significant difference in the outcome between the two subgroups $\left(\chi^{2}: 0.004 ; p=0.952\right)$ (data not shown). In contrast, probability of the renal endpoint was significantly higher with increased arterial stiffness $\left(\chi^{2}: 5.591 ; p=0.018\right)$ (Fig. 1B).

We performed ROC analysis to determine the SI value obtained through the method finger photoplethysmography, which most appropriately separates the two subgroups for any outcome, and this $\mathrm{SI}_{\mathrm{DVP}}$ value was $10.66 \mathrm{~m} / \mathrm{s}$.

The Cox regression model showed that every $1 \mathrm{~m} / \mathrm{s}$ increase of the SI increased the probability of the cumulative endpoint by $18.7 \%$ [odds ratio: 1.187 (CI: $1.001-1.408$ ); $p=0.048$ ]. 
Table II. Occurrence of primary and secondary end points in the ADPKD patients

\begin{tabular}{|l|c|c|c|c|}
\hline & & & \multicolumn{2}{|c|}{ Secondary endpoints } \\
\cline { 4 - 5 } & Patients number $(\boldsymbol{n})$ & $\begin{array}{c}\text { Primary, combined } \\
\text { endpoints }[\boldsymbol{n}(\%)]\end{array}$ & Renal $[\boldsymbol{n}(\%)]$ & $\begin{array}{c}\text { Cardiovascular } \\
{[\boldsymbol{n}(\%)]}\end{array}$ \\
\hline $\mathrm{SI}_{\mathrm{DVP}} \leq 11 \mathrm{~m} / \mathrm{s}$ & 27 & $12(44)$ & $9(33)$ & $3(11)$ \\
\hline $\mathrm{SI}_{\mathrm{DVP}}>11 \mathrm{~m} / \mathrm{s}$ & 28 & $18(64)$ & $12(43)$ & $6(21)$ \\
\hline Total events $[n(\%)]$ & & $30(53)$ & $21(38)$ & $9(16)$ \\
\hline
\end{tabular}

$\mathrm{SI}_{\mathrm{DVP}}$ : stiffness index; ADPKD: autosomal dominant polycystic kidney disease

Multivariate analysis of variance was used to explore those factors that could predict CV events and renal functional decline, independently of other parameters; in this model, only baseline renal function (eGFR) has proved to be an independent prognostic factor for the combined CV and renal outcomes (Table III; $p<0.001$ ).

There were significantly more $\mathrm{CV}$ events in the group of patients with metabolic syndrome than in the group of patients without it $\left(\chi^{2}: 6.246 ; p=0.012\right)$ (Fig. 2). $\mathrm{SI}_{\mathrm{DVP}}$ of the patients with metabolic syndrome was significantly higher than those of patients without it $(12.1 \pm 2.3 \mathrm{~m} / \mathrm{s}$ vs. $10.8 \pm 2.1 \mathrm{~m} / \mathrm{s} ; p=0.036)$. Cox regression analysis showed that metabolic syndrome was an independent predictor for CV endpoints $(p=0.022)$, but not for the combined primary and secondary renal endpoints (Table IV).

\section{Discussion}

We have found that increased arterial stiffness was an independent prognostic factor for the combined CV and renal outcomes in ADPKD patients. Arterial stiffness measured by Pulse Trace System appears as a useful and applicable method for estimating the renal and CV prognosis in ADPKD.

\section{Increased arterial stiffness in CKD}

It was demonstrated several years ago that arterial stiffness is markedly increased in ESRD (9, $13,17,28,29,44)$. Recent data indicated that arterial stiffening is increased in CKD, even in patients with mild to moderate loss of renal function or in the presence of microalbuminuria $(7,46,47,50)$.

The pathophysiological mechanism of increased arterial stiffness observed in CKD is not entirely defined. Several putative mechanisms have been implicated, including chronic hypervolemia, chronic microinflammation, lipid peroxidation, suppression of the nitric oxide system, excessive sympathetic activity, activation of the renin-angiotensin-aldosterone system (RAAS), as well as increased mechanical stress due to either hypertension or the arterial wall calcification $(19,30)$.

\section{Increased arterial stiffness and ADPKD}

ADPKD patients exhibit vascular dysfunction as increased arterial stiffness and this stiffness is evident very early in the course of ADPKD even in patients with normal renal function $(5,40)$. In a previous cross-sectional study, we showed that arterial stiffness is increased as the renal function declined in a homogeneous group of CKD patients with IgAN (22). 


\section{Cumulative survival}

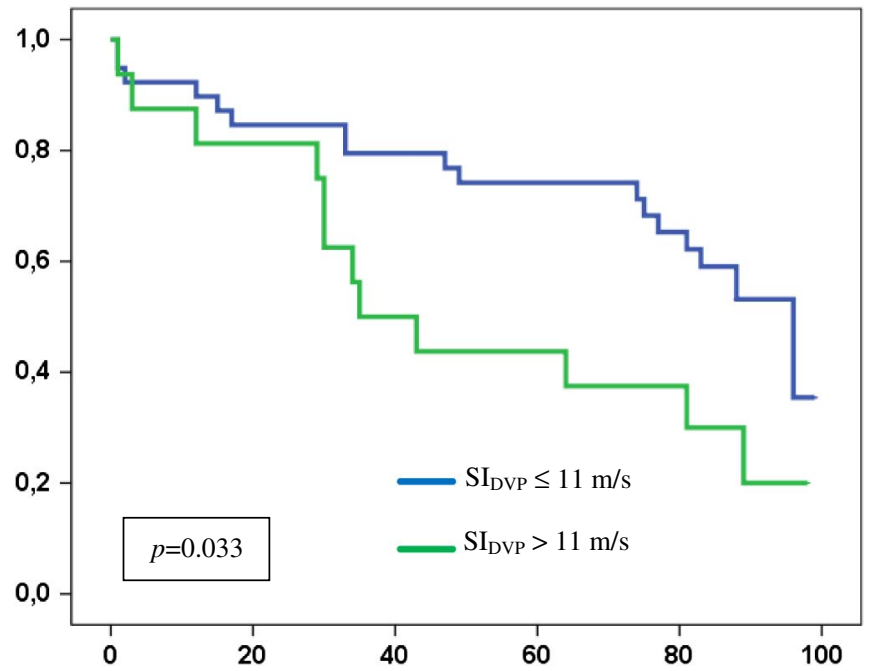

Time to first event or end of follow-up (month)

(a)

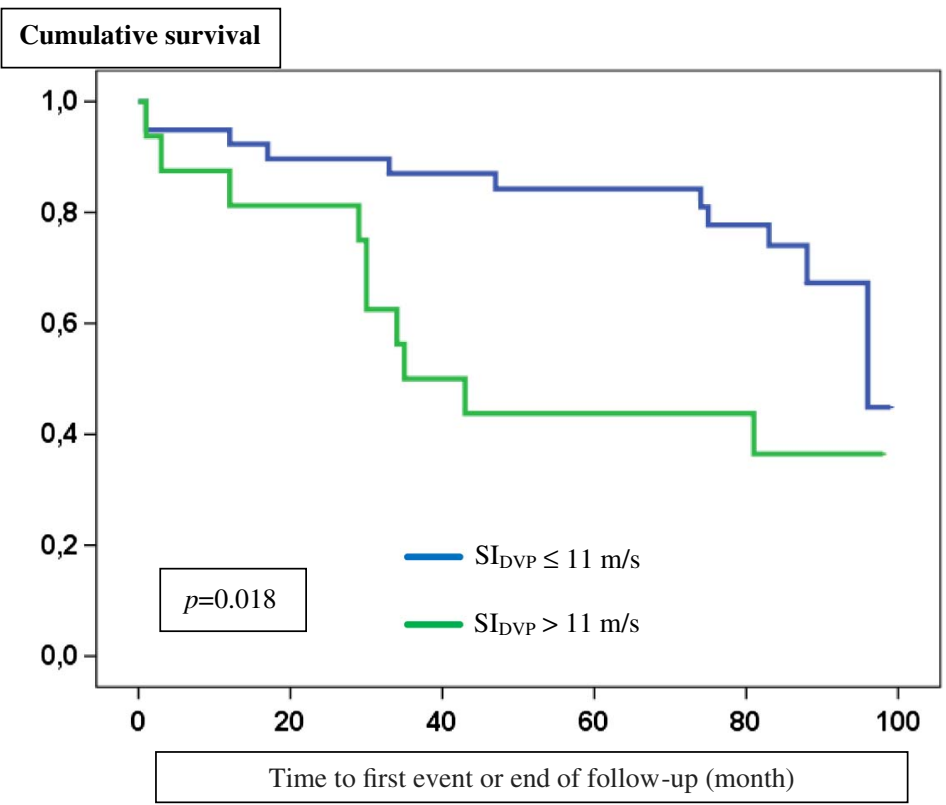

(b)
Fig. 1. (A) Primary, combined endpoints in ADPKD patients with $\mathrm{SI}_{\text {DVP }}>11 \mathrm{~m} / \mathrm{s}$ versus $\mathrm{SI}_{\mathrm{DVP}} \leq 11 \mathrm{~m} / \mathrm{s}$. (B) Secondary renal endpoints in ADPKD patients with $\mathrm{SI}_{\text {DVP }}>11 \mathrm{~m} / \mathrm{s}$ versus $\mathrm{SI}_{\text {DVP }} \leq 11 \mathrm{~m} / \mathrm{s}$

Moreover, we concluded that the etiology of CKD may also affect the degree of arterial stiffness by comparing IgAN and ADPKD patients, as our findings have shown that arterial stiffness develops earlier and the progression is more rapid in ADPKD than in IgAN patients with comparable renal function (22). 
Table III. The prognostic role of each parameter in association with combined primary endpoints (multivariate analysis)

\begin{tabular}{|c|c|c|c|c|c|c|}
\hline & $B$ & SE & Wald & $d f$ & $p$ & $\operatorname{Exp}(B)$ \\
\hline $\mathrm{SI}_{\mathrm{DVP}}$ & -0.049 & 0.114 & 0.182 & 1 & 0.670 & 0.952 \\
\hline Age & -0.017 & 0.022 & 0.603 & 1 & 0.437 & 0.983 \\
\hline eGFR & -0.055 & 0.010 & 28.208 & 1 & $<0.001$ & 0.946 \\
\hline Gender & -0.884 & 0.455 & 3.786 & 1 & 0.052 & 0.413 \\
\hline Hypertension & -0.924 & 0.896 & 1.063 & 1 & 0.303 & 0.397 \\
\hline $\begin{array}{c}\text { Carbohydrate } \\
\text { metabolic } \\
\text { disorder }\end{array}$ & 0.016 & 0.507 & 0.001 & 1 & 0.975 & 1.016 \\
\hline Dyslipidemia & 0.810 & 0.528 & 2.350 & 1 & 0.125 & 2.247 \\
\hline Obesity & -0.686 & 0.550 & 1.558 & 1 & 0.212 & 0.504 \\
\hline
\end{tabular}

$B$ : beta coefficient; SE: standard error; eGFR: estimated glomerular filtration rate

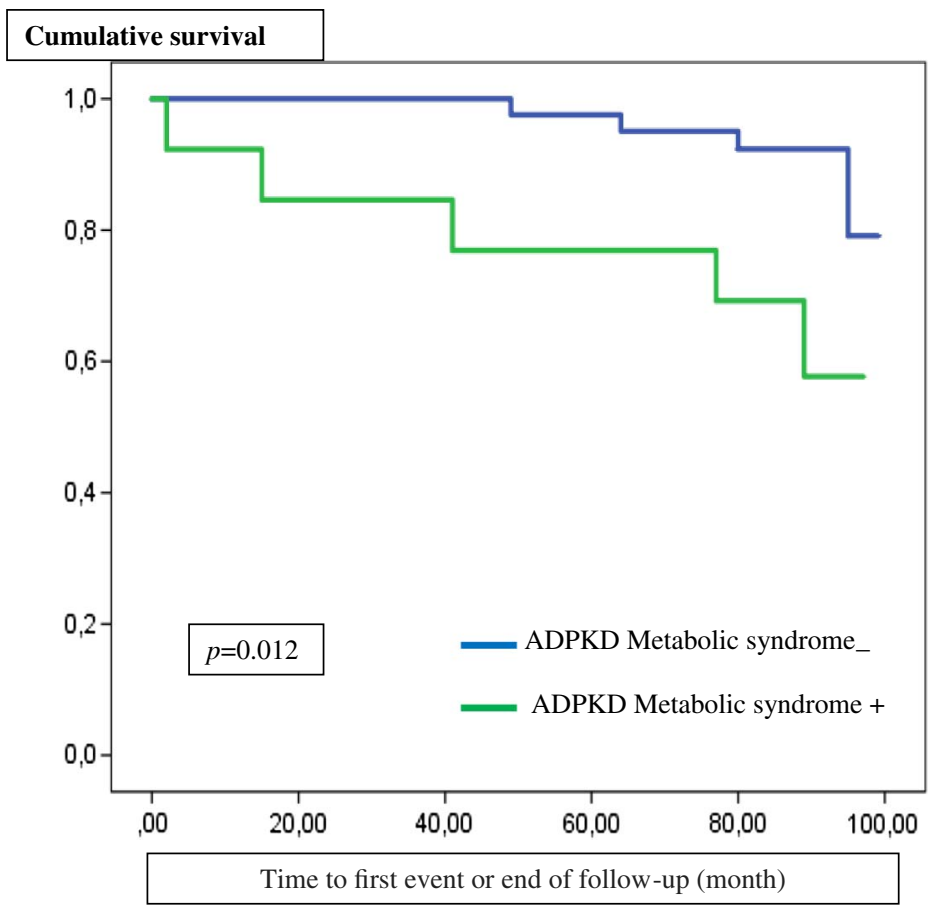

Fig. 2. Secondary cardiovascular endpoints in ADPKD patients with metabolic syndrome versus without metabolic syndrome

The pathomechanism of the vascular lesions in ADPKD

The pathomechanism of the premature CV lesions in ADPKD is not fully understood; however, several factors could be involved in the development of $\mathrm{CV}$ abnormalities in ADPKD. Nauli et al. (37) implied that vascular dysfunction in ADPKD may be a 
Table $I V$. The prognostic role of metabolic syndrome in association with primary and secondary endpoints in ADPKD (Cox regression analysis)

\begin{tabular}{|l|c|c|c|c|c|c|c|}
\hline & $\begin{array}{c}\text { Hazard } \\
\text { ratio }\end{array}$ & \multicolumn{2}{|c|}{$\mathbf{9 5 \%}$ CI } & Coefficient & SE & $Z$-statistic & $p$ value \\
\hline $\begin{array}{l}\text { Primary, combined } \\
\text { endpoints }\end{array}$ & 2.046 & 0.949 & 4.410 & 0.716 & 0.391 & 1.827 & 0.067 \\
\hline $\begin{array}{l}\text { Cardiovascular } \\
\text { endpoints }\end{array}$ & 4.676 & 1.239 & 17.641 & 1.542 & 0.677 & 2.277 & $0.022 *$ \\
\hline Renal endpoints & 1.065 & 0.389 & 2.916 & 0.063 & 0.513 & 0.123 & 0.902 \\
\hline
\end{tabular}

CI: confidence interval; SE: standard error; ADPKD: autosomal-dominant polycystic kidney disease. $* p=0.022$

consequence of an inherited disorder of endothelial cilia. The disorder of the primary cilium, which covers the internal surface of endothelial cells of the blood vessels, may trigger a biochemical cascade mechanism leading to decreased nitric monoxide (NO) availability and endothelial dysfunction $(1,37)$. As a result, vascular remodeling by the cilium dysgenesis may develop due to impaired cell differentiation and altered connective tissue structure, thus leading to increased vascular rigidity. Consistently, the plasma concentration of NO was lower in ADPKD $(16,48,49)$.

In another hypothesis, the cause of vascular complications in ADPKD could be explained by the polycystic kidney itself. Briefly, enlarged kidney cysts causing structural damage of the nephrons and distortion of the normal kidney structure lead to intrarenal ischemia that activates the RAAS system, which has important roles in CV remodeling. Activation of RAAS occurs very early in ADPKD patients, in both adults and children, often preceding the onset hypertension and renal failure $(36,39,45)$. Hyperplasia of the reninproducing cells in the juxtaglomerular apparatus could be observed in the removed kidneys of ADPKD patients, referring to the involvement of RAAS activity (45). The vast majority of our ADPKD patients were treated with RAAS inhibitors, and thus we have no data to draw any conclusion on this.

Kocyigit et al. (24) showed relationship between early arterial stiffness and inflammatory biomarkers in normotensive ADPKD patients by showing that arterial stiffness was increased prior to the onset of hypertension or renal function decline, and interleukin-6, tumor necrosis factor- $\alpha$, and C-reactive protein levels were all significant predictors of PWV. This finding indicates the presence of low-grade, systemic inflammatory processes that contribute to early arterial damage and thus to the resultant arterial stiffness in ADPKD (24).

\section{Renal and CV outcome and increased vascular stiffness}

Epidemiologic longitudinal studies have clearly demonstrated that arterial stiffness has an independent predictive value of $\mathrm{CV}$ outcomes in different populations $(10,26,27,51)$. Blacher et al. (4) found that every $1 \mathrm{~m} / \mathrm{s}$ elevation of PWV increased the CV and total mortality by $14 \%$ in ESRD. Recently, Nowak et al. (40) reported that impaired endotheliumdependent vasodilation and enhanced arterial stiffness were independent predictors of $\mathrm{CV}$ events and mortality in children and young adults with ADPKD having preserved renal function. 


\section{Metabolic abnormalities in ADPKD}

Mao et al. (32) described in a review that a wide range of metabolic abnormalities have been reported as part of the clinical spectrum of ADPKD. Pietrzak-Nowacka et al. (42) showed several components of metabolic syndrome, such as hypertension, abdominal obesity, and higher fasting blood glucose level in ADPKD. However, there remains uncertainty as to the consistency of these findings in different populations and the precise underlying molecular mechanisms that link them to the genetic defects in ADPKD (32).

In his reviews $(11,12)$, Ecder also calls attention to the early occurrence of $\mathrm{CV}$ complications in ADPKD and recommends multifactorial risk-reduction (hypertension, obesity, dyslipidemia, and smoking). Particularly, the most important is early detection of hypertension to prevent vascular complications and the use of angiotensinconverting enzyme inhibitor (ACEI) treatment to reduce CV events $(11,12,35,36)$. In this study, $84 \%$ of ADPKD patients take ACEI or angiotensin-receptor blocking agent to treat their hypertension, which could positively alter the $\mathrm{SI}_{\mathrm{DVP}}$ and the CV outcome of the patients (31).

\section{Methods for measurement of arterial stiffness}

Arterial stiffness can be measured by several methods (38). In this follow-up study, we applied finger photoplethysmography method using the Pulse Trace System to measure $\mathrm{SI}_{\mathrm{DVP}}$. $\mathrm{SI}_{\mathrm{DVP}}$ is a composite parameter influenced by flexibility of the large central arteries as well as by reflective properties of the peripheral arteries. The usefulness of the $\mathrm{SI}_{\mathrm{DVP}}$ was already successfully tested in healthy individuals and in patients with hypertension, diabetes mellitus, coronary arterial disease, and $\operatorname{ESRD}(3,21)$. Furthermore, $\mathrm{SI}_{\text {DVP }}$ helped in risk stratification of both hypertensive and apparently healthy people with different CV risk factors $(8,18)$. However, the method was not used before our previous $(22)$ and present studies for the stiffness measurement of ADPKD patients.

\section{Study limitations}

The results of this study demonstrated that arterial stiffness measured by finger photoplethysmography has a prognostic value, although occasionally there are difficulties in registering the digital pulse volume. It may be problematic in some cases, mostly in elder patients to confidently separate systolic and reflective waves, and thus assess the SI. Atrial fibrillation and frequent atrial and ventricular ectopic activities could also limit the detection of correct pulse curves. We estimated and not measured the renal function; however, the use of eGFR is widely accepted throughout the literature. The study may be weakened by the low number of our cases. It is conceivable that study follow-up period was rather short to be sufficient to prove the difference in the occurrence of CV events and renal failure.

\section{Conclusions}

We conclude that increased arterial stiffness predicts the occurrence of ESRD and CV endpoints in ADPKD, particularly, in patients with multiple CV risk factors; hence, early measurement of arterial stiffness can be recommended. Further studies are required with DVP (arterial SI) measurements using the Pulse Trace System to get this method widely accepted for predicting the renal progression and $\mathrm{CV}$ events in $\mathrm{CKD}$. 


\section{Acknowledgements}

The authors would like to thank Dr. Ilona Varga Sámikné for her conscientious work in the research and records of the data. This publication is dedicated to the memory of the 650th anniversary of the foundation of University of Pécs. Some of the results of this paper have already been reported in Hungarian language (see 43).

\section{REFERENCES}

1. Abou-Aliawi WA, Takahashi M, Mell BR, Jones TJ, Ratnam S, Kolb RJ, Nauli SM: Ciliary polycystin-2 is a mechanosensitive calcium channel involved in nitric oxide signaling cascades. Circ. Res. 104, 860-869 (2009)

2. Alty SR, Angarita-Jaimes N, Millasseau SC, Chowienczyk PJ: Predicting arterial stiffness from the digital volume pulse waveform. IEEE Trans. Biomed. Eng. 54, 2268-2275 (2007)

3. Benczúr B, Böcskei R, Cziráki A, Illyés M: The added value of aortic PWV beyond traditional risk factors in cardiovascular risk stratification. Atherosclerosis 252, 218-219 (2016)

4. Blacher J, Guerin AP, Pannier B, Marchais SJ, Safar ME, London GM: Impact of aortic stiffness on survival in end-stage renal disease. Circulation 99, 2434-2439 (1999)

5. Borresen ML, Wang D, Strandgaard S: Pulse wave reflection is amplified in normotensive patients with autosomal-dominant polycystic kidney disease and normal renal function. Am. J. Nephrol. 27, 240-246 (2007)

6. Bots ML, Hoes AW, Kousstaal PJ, Hofman A, Grobbee DE: Common carotid intima-media thickness and risk of stroke and myocardial infarction: the Rotterdam Study. Circulation 96, 1432-1437 (1997)

7. Briet M, Bozec E, Laurent S, Fassot C, London GM, Jacquot C, Froissart M, Houillier P, Boutouyrie P: Arterial stiffness and enlargement in mild-to-moderate chronic kidney disease. Kidney Int. 69, 350-357 (2006)

8. Chen JY, Tsai WC, Lin CC, Huang YY, Hsu CH, Liu PY, Chen JH: Stiffness index derived from digital volume pulse as a marker of target organ damage in untreated hypertension. Blood Press. 14, 233-237 (2005)

9. Covic A, Gusbeth-Tatomir P, Goldsmith DJA: Arterial stiffness in renal patients: an update. Am. J. Kidney Dis. 45, 965-977 (2005)

10. Cruickshank K, Riste L, Anderson SG, Wright JS, Dunn G, Gosling RG: Aortic pulse-wave velocity and its relationship to mortality in diabetes and glucose intolerance: an integrated index of vascular function? Circulation 106, 2085-2090 (2002)

11. Ecder T: Cardiovascular complications in autosomal dominant polycystic kidney disease. Curr. Hypertens. Rev. 9, 2-11 (2013)

12. Ecder T, Schrier RW: Cardiovascular abnormalities in autosomal-dominant polycystic kidney disease. Nat. Rev. Nephrol. 5, 221-228 (2009)

13. El Hadj Othmane T, Nemcsik J, Fekete BCs, Deák G, Egresits J, Fodor E, Logan AG, Németh ZK, Járai Z, Szabó T, Szathmári M, Kiss I, Tislér A: Arterial stiffness in hemodialysis: which parameter to measure to predict cardiovascular mortality? Kidney Blood Press. Res. 32, 250-257 (2009)

14. Fick GM, Johnson AM, Hammond WS, Gabow PA: Causes of death in autosomal polycystic kidney disease. J. Am. Soc. Nephrol. 5, 2046-2056 (1995)

15. Go AS, Mozaffarian D, Roger VL, Benjamin EJ, Berry JD, Blaha MJ, Dai S, Ford ES, Fox CS, Franco S, Fullerton HJ, Gillespie C, Hailpern SM, Heit JA, Howard VJ, Huffman MD, Judd SE, Kissela BM, Kittner SJ, Lackland DT, Lichtman JH, Lisabeth LD, Mackey RH, Magid DJ, Marcus GM, Marelli A, Matchar DB, McGuire DK, Mohler ER 3rd, Moy CS, Mussolino ME, Neumar RW, Nichol G, Pandey DK, Paynter NP, Reeves MJ, Sorlie PD, Stein J, Towfighi A, Turan TN, Virani SS, Wong ND, Woo D, Turner MB, American Heart Association Statistics Committee and Stroke Statistics Subcommittee: Executive summary: heart disease and stroke statistics - 2014 update: a report from the American Heart Association. Circulation 129, 399-410 (2014)

16. Griffin MD, Torres WE, Grande JP, Kumar R: Vascular expression of polycystin. J. Am. Soc. Nephrol. 8, 616-626 (1997)

17. Guerin AP, Blacher J, Pannier B, Marchais SJ, Safar ME, London GM: Impact of aortic stiffness attenuation on survival of patients in end-stage renal failure. Circulation 103, 987-992 (2001)

18. Gunarathne A, Patel JV, Hughes EA, Lip GY: Measurement of stiffness index by digital volume pulse analysis technique: clinical utility in cardiovascular disease risk stratification. Am. J. Hypertens. 21, 866-872 (2008)

19. Gusbeth-Tatomir P, Covic A: Causes and consequences of increased arterial stiffness in chronic kidney disease patients. Kidney Blood Press. Res. 30, 97-107 (2007) 
20. Harris T, Sandford R, de Coninck B, Devuyst O, Drenth JPH, Ecder T, Kent A, Gansevoort RT, Górriz JL, Ong ACM, Pirson Y, Torres VE, Budde K, CÍment D, Derchi LE, Eleftheroudi M, Levtchenko E, Peters D, Van Poppel H, Vanholder R: European ADPKD Forum multidisciplinary position statement on autosomal dominant polycystic kidney disease care: European ADPKD Forum and Multispecialist Roundtable participants. Nephrol. Dial. Transplant. 33, 563-573 (2018)

21. Hashimoto J, Watabe D, Kimura A, Takahashi H, Ohkubo T, Totsune K, Imai Y: Determinants of the second derivate of the finger photoplethysmogram and brachial-ankle pulse-wave velocity: the Okasama study. Am. J. Hypertens. 18, 477-485 (2005)

22. Késôi I, Sági B, Tóth OI, Vas T, Fazekas A, Kovács T, Pintér T, Wittmann I, Nagy J: Different effect of IgA nephropathy and polycystic kidney disease on arterial stiffness. Kidney Blood Press. Res. 34, 158-166 (2011)

23. Kocaman O, Oflaz H, Yeleker E, Dursun M, Erdogan D, Demirel S, Alisir S, Turgut F, Mercanoglu F, Ecder T: Endothelial dysfunction and increased carotid intima-media thickness in patients with autosomal dominant polycystic kidney disease. Am. J. Kidney Dis. 43, 854-860 (2004)

24. Kocyigit I, Kaya MG, Orscelik O, Kaya C, Akpek M, Zengin H, Sipahioglu MH, Unal A, Yilmaz MI, Tokgoz B, Oymak O, Axelsson J: Early arterial stiffness and inflammatory bio-markers in normotensive polycystic kidney disease patients. Am. J. Nephrol. 36, 11-18 (2012)

25. Lakatta EG, Levy D: Arterial and cardiac aging: major shareholders in cardiovascular disease enterprises: Part I: aging arteries: a "set up" for vascular disease. Circulation 107, 139-146 (2003)

26. Laurent S, Boutouyrie P, Asmar R, Gautier I, Laloux B, Guize L, Ducimetiere P, Benetos A: Aortic stiffness is an independent predictor of all-cause and cardiovascular mortality in hypertensive patients. Hypertension 37 , 1236-1241 (2001)

27. Laurent S, Katsahian S, Fassot C, Tropeano AI, Gautier I, Laloux B, Boutouyrie P: Aortic stiffness is an independent predictor of fatal stroke in essential hypertension. Stroke 34, 1203-1206 (2003)

28. London GM, Guerin AP, Marchais SJ, Métivier F, Pannier B, Adda H: Arterial media calcification in end-stage renal disease: impact on all-cause and cardiovascular mortality. Nephrol. Dial. Transplant. 18, 1731-1740 (2003)

29. London GM, Marchais SJ, Guérin AP, Métivier F: Arteriosclerosis, vascular calcifications and cardiovascular disease in uraemia. Curr. Opin. Nephrol. Hypertens. 14, 525-531 (2005)

30. London GM, Marchais SJ, Guerin AP, Pannier B: Arterial stiffness: pathophysiology and clinical impact. Clin. Exp. Hypertens. 26, 689-699 (2004)

31. Mancia G, Fagard R, Narkiewicz K, Redon J, Zanchetti A, Böhm M, Christiaens T, Cifkova R, De Backer G, Dominiczak A, Galderisi M, Grobbee DE, Jaarsma T, Kirchhof P, Kjeldsen SE, Laurent S, Manolis AJ, Nilsson PM, Ruilope LM, Schmieder RE, Sirnes PA, Sleight P, Viigimaa M, Waeber B, Zannad F, ESH Scientific Council, Redon J, Dominiczak A, Narkiewicz K, Nilsson PM, Burnier M, Viigimaa M, Ambrosioni E, Caufield M, Coca A, Olsen MH, Schmieder RE, Tsioufis C, van de Borne P, ESC Committee for Practice Guidelines (CPG), Zamorano JL, Achenbach S, Baumgartner H, Bax JJ, Bueno H, Dean V, Deaton C, Erol C, Fagard R, Ferrari R, Hasdai D, Hoes AW, Kirchhof P, Knuuti J, Kolh P, Lancellotti P, Linhart A, Nihoyannopoulos P, Piepoli MF, Ponikowski P, Sirnes PA, Tamargo JL, Tendera M, Torbicki A, Wijns W, Windecker S, Clement DL, Coca A, Gillebert TC, Tendera M, Rosei EA, Ambrosioni E, Anker SD, Bauersachs J, Hitij JB, Caulfield M, De Buyzere M, De Geest S, Derumeaux GA, Erdine S, Farsang C, Funck-Brentano C, Gerc V, Germano G, Gielen S, Haller H, Hoes AW, Jordan J, Kahan T, Komajda M, Lovic D, Mahrholdt H, Olsen MH, Ostergren J, Parati G, Perk J, Polonia J, Popescu BA, Reiner Z, Rydén L, Sirenko Y, Stanton A, Struijker-Boudier H, Tsioufis C, van de Borne P, Vlachopoulos C, Volpe M, Wood DA: $2013 \mathrm{ESH} / \mathrm{ESC}$ guidelines for the management of arterial hypertension: the Task Force for the Management of Arterial Hypertension of the European Society of Hypertension (ESH) and of the European Society of Cardiology (ESC). Eur. Heart J. 34, 2159-2219 (2013)

32. Mao Z, Xie G, Ong ACM: Metabolic abnormalities in autosomal dominant polycystic kidney disease. Nephrol. Dial. Transplant. 30, 197-203 (2015)

33. Millasseau SC, Kelly RP, Ritter JM, Chowienczyk PJ: Determination of age-related increases in large artery stiffness by digital pulse contour analysis. Clin. Sci. 103, 371-377 (2002)

34. Millasseau SC, Ritter JM, Takazawa K, Chowienczyk PJ: Contour analysis of the photopletysmographic pulse measured at the finger. J. Hypertens. 24, 1449-1456 (2006)

35. Nagy J, Kovács T, Wittmann I: Renal protection in IgA nephropathy requires strict blood pressure control. Nephrol. Dial. Transplant. 20, 1533-1539 (2005)

36. Nauli SM: An ACE inhibitor imporves vascular outcomes in PKD model. Am. J. Physiol. Renal. Physiol. 301, F958 (2011) 
37. Nauli SM, Kawanabe Y, Kamninski JJ, Pearce WJ, Ingber DE, Zhou J: Endothelial cilia are fluid shear sensor that regulate calcium signaling and nitric oxide production through polycystine-1. Circulation 117, 1161-1171 (2008)

38. Nemcsik J, Cseprekál O, Tislér A: Measurement of arterial stiffness: a novel tool of risk stratification in hypertension. Adv. Exp. Med. Biol. 956, 475-488 (2017)

39. Ng K, Hildreth CM, Avolio AP, Phillips JK: Angiotensin-converting enzyme inhibitor limits pulse-wave velocity and aortic calcification in rat model of cystic renal disease. Am. J. Physiol. Renal. Physiol. 300, 1431-1436 (2011)

40. Nowak KL, Farmer H, Cadnapaphornchai MA, Gitomer B, Chonchol M: Vascular dysfunction in children and young adults with autosomal dominant polycystic kidney disease. Nephrol. Dial. Transplant. 32, 342-347 (2017)

41. Perrone RD, Ruthazer R, Terrin NC: Survival after end-stage renal disease in autosomal dominant polycystic kidney disease: contribution of extrarenal complications to mortality. Am. J. Kidney Dis. 38, 777-784 (2001)

42. Pietrzak-Nowacka M, Safranow K, Byra E, Bińczak-Kuleta A, Ciechanowicz A, Ciechanowski K: Metabolic syndrome components in patients with autosomal-dominant polycystic kidney disease. Kidney Blood Press. Res. 32, 405-410 (2009)

43. Sági B, Késői B, Késői I, Vas T, Kovacs T, Wittmann I, Nagy J: Az ujjpletizmográffal meghatározott stiffness index prognosztikai szerepe polycystás vesebetegség esetén [The prognostic role of stiffness index measured by finger photoplethismography in polycystic kidney disease]. Hypertonia és Nephrologia (Hungarian) 21, 120-127 (2017)

44. Sollinger D, Mohaupt MG, Wilhelm A, Uehlinger D, Frey FJ, Eisenberger U: Arterial stiffness assessed by digital volume pulse correlates with comorbidity in patients with ESRD. Am. J. Kidney Dis. 48, 456-463 (2006)

45. Torres WE, Harris PC, Pirson Y: Autosomal dominant polycystic kidney disease. Lancet 369, 1287-1301 (2007)

46. Townsend RR, Wimmer NJ, Chirinos JA, Parsa A, Weir M, Perumal K, Lash JP, Jing Chen J, Steigerwalt SP, Flack J, Go AS, Rafey M, Rahman M, Sheridan A, Gadegbeku CA, Robinson NA, Joffe M: Aortic PWV in chronic kidney disease: a CIRC Ancillary Study. Am. J. Hypertens. 23, 282-289 (2010)

47. Upadhyay A, Hwang SJ, Mitchell GF, Vasan RS, Vita JA, Stantchev PI, Meigs JB, Larson MG, Levy D, Benjamin EJ, Fox CS: Arterial stiffness in mild-to-moderate CKD. J. Am. Soc. Nephrol. 20, 2044-2053 (2009)

48. Wang D, Iversen J, Strandgaard S: Endothelium-dependent relaxation of small resistance vessels is impaired in patients with autosomal dominant polycystic kidney disease. J. Am. Soc. Nephrol. 11, 1371-1376 (2000)

49. Wang D, Iversen J, Wilcox CS, Strandgaard S: Endothelial dysfunction and reduced nitric oxide in resistance arteries in autosomal-dominant polycystic kidney disease. Kidney Int. 64, 1381-1388 (2003)

50. Wang MC, Tsai WC, Chen JY, Huang JJ: Stepwise increase in arterial stiffness corresponding with the stages of chronic kidney disease. Am. J. Kidney Dis. 45, 494-501 (2005)

51. Willum-Hansen T, Staessen JA, Torp-Pedersen C, Rasmussen S, Thijs L, Ibsen H, Jeppesen J: Prognostic value of aortic pulse wave velocity as index of arterial stiffness in the general population. Circulation 113, 664-670 (2006) 